Mira Bekar

Ss. Cyril and Methodius University, Skopje, Macedonia; Purdue University, West Lafayette, IN, USA

\title{
Writing curricula design: Aims and practices
}

\section{Introduction}

In order to accomplish their professional goals and be compatible at the world job market L2 student writers need to acquire the sufficient tools to write effectively. Designing productive writing curricula is one of the major responsibilities of writing instructors.

Establishing a new curriculum at any educational institution is a cumbersome, very responsible, and challenging task, but the outcome is rewarding and beneficial for various target groups in the society. In this paper, I will describe an initiative for creating writing courses at the English Department at Ss Cyril and Methodius University, Macedonia, providing information about the required steps in introducing new curricula. I believe that the case presented here touches many valuable issues that are common with other universities, so this text may initiate future dialogue among writing instructors working on designing and developing writing courses in the region (the Balkans and South-East Europe).

The reasons for establishing writing curricula can be of various natures: educational (e.g., improving the overall literacy), professional (e.g., training teachers to teach writing, establishing new undergraduate and graduate studies), national (e.g., strengthening the written communication skills of professionals in the areas of business and economy) and so on.

If we look at foreign practices of implementing new writing curricula, specifically those in the US, we can see views similar to those in Eastern and South-Eastern; that is, while writing has been perceived to be an integral element 
to academic success and effective participation in an educated society, many teachers and students believe writing should be more present at educational institutions because of its importance. Writing should not only be an integral but also an essential part of any foreign language teaching curricula, because it proves beneficial for the development of students' cognitive, analytic and communication skills. In its report, The Neglected " $R$ ": The Need for a Writing Revolution, the National Commission on Writing revealed that "writing was one of the most neglected elements of teaching in American schools in today's hardpressed society." (Harrison 2006: 16). The National Commission on Writing report states,

If students are to make knowledge on their own, they must struggle with the details, wrestle with the facts, and rework raw information and dimly understood concepts into language they can communicate to someone else. In short, if students are to learn, they must write. (NCW 2003: 9)

This quote, similarly to many other calls for action coming from writing experts and educational boards, illustrates the importance of commitment to developing a curriculum to teach writing since writing, compared to other curricula, is an underdeveloped area in curriculum and instruction.

In the South-East European context, the underdevelopment of writing curricula compared to other curricula is noticeable. From my personal experience as a language and writing instructor at the English Department at Ss Cyril and Methodius University in Macedonia and from the informal discussions with my colleagues, the gap has been perceived between what English majors learn through the existing curriculum and what they need to know for their future career. The situation at the English department mirrors the situation at other language departments. The existing program educates students for elementary and high school teachers, translators and interpreters. However, they are not fully prepared for the real-world responsibilities when they graduate. They lack the appropriate training and expertise to teach a foreign language through writing and lack skills for effective written communication which is in a way standardized in various professional fields. As for the immediate context, students need to improve their writing skills since $35-40 \%$ of those students fail their literature exams. In order to fill the existing gap and solve these problems an effective writing curriculum is more than necessary; a curriculum that will be aiming at raising the quality of learners' academic and professional writing skills.

Another reason which urges design and implementation of writing curricula lies in the fact that in recent years, the mobility of students in Europe has increased due to new countries entering the $\mathrm{EU}$, as well as the visa liberation processes have been introduced for certain countries which are potential candidates for the EU. Students have many opportunities to continue their graduate education abroad, where good writing skills to produce a term paper in a foreign language are a basic necessity for their academic success. The European credit transfer 
system was introduced at Macedonian Universities in 2004. Still in a developing phase, it offers opportunity for further development of writing courses to reflect the overall study needs and also to prepare students for the possibility of studying at other European universities. The underdeveloped writing skills of students are seriously affected by the lack of opportunities to write in a foreign language outside the classroom; except maybe for using foreign languages for email correspondence or online chat. To conclude, students need and want to achieve better results on literature exams, be educated according to the world educational trends, and be prepared to meet the world job market requirements. All these factors imply that educational institutions should pay more attention to establishing and developing their writing curricula.

\section{Profile of the situation}

In this section, I will give a profile of a situation with the writing curricula at one institution of higher education and report on the changes in the existing writing curricula. Prior to 2004, at the Macedonian university where I studied and work now, there was only one British instructor teaching a small portion of writing in English to junior and senior students who were majoring in English language and literature. The other language departments did not offer any writing courses at that time. All foreign language courses put emphasis on error correction and grammar practice. Writing was considered to be just another tool to test student's language competence in a narrow sense, and was not taught as a skill in its own right. Moreover,

students lacked awareness of the formal conventions of writing between Macedonian and English which are different in many ways, for instance, differences in rhetorical standards, layout and punctuation. (Georgievska, Kirkova-Naskova \& Oncevska 2007: 215)

Furthermore, writing skills were always taught by native-English speaking lecturers, usually visiting scholars or Fulbright fellows. Macedonian lecturers at that time, since never having been trained, did not feel they had adequate skills to teach writing. In high school, students received only sporadic training in writing skills in English or in their L1 (Macedonian). The situation in high-schools has changed with the introduction of a new English Matura exam (a final high-school exam) which incorporates testing students' writing skills. In this paper, I will not discuss further the current situation of writing courses in secondary education, since the emphasis in this work is on the writing curricula at the institution of higher education.

The lack of writing courses and observations on the needs of the students majoring in English language and literature, in regard to improving their overall literacy and specific writing skills in English, resulted in an initiative to start 
a project on creating and implementing a 4-year curriculum. From May 2004March 2007, a Writing University Project was carried out at the Department of English Language and Literature, at Ss Cyril and Methodius University, in collaboration with the British Council in Macedonia. It aimed to show that by creating a 4-year writing syllabus, the participants in the project would improve their skills as teachers and to a certain extent this would change their beliefs about writing as an activity embedded in culture, while at the same time catering to the needs of the students. A visiting writing expert from the UK, Professor O'Brien, was in charge of the three seminars held in 2004-2005. The following objectives were identified:

1. raising awareness of different rhetorical traditions (intercultural);

2. raising awareness of the importance of "audience";

3. raising awareness of the role of writing in study skills;

4. motivating students to develop accuracy;

5. developing students' cognitive capacities through writing.

The Writing University Project resulted in training eight Macedonian lecturers to teach writing and in preparation of original materials for a fouryear writing course. The focus in the first two semesters was put on paragraph writing of descriptive and narrative texts. What followed in the third and forth semester (year 2) was linking the paragraphs into an essay with special focus on editing and peer-review strategies covering various genres. The focus in the third year was put on writing formal letters and research articles, while the last year was devoted to creative writing. i.e., students were taught to write poems, short stories and a script. Currently, writing is just a small part of a big course called Contemporary English language, a required 4-year course, which is a melting pot of reading, listening, speaking, writing, and translation instruction. Only 1 hour and 30 minutes per week are spent on writing instruction.

These newly established writing courses and the material were evaluated by freshmen and sophomores. The survey, conducted in 2005, showed that besides improving their writing skills, students developed cognitive and analytical skills, specifically, felt more confident in reading and understanding complex texts, and summarizing (Reid, Bekar \& Kirkova-Naskova 2005). The writing courses are helping students to develop abilities to select and evaluate information, express opinions, hypothesize and persuade-all the skills relevant to make them highly competent for their future careers. The results supported the view of writing experts that if students want to learn a foreign language, they must learn to write in that language.

Since 2007, the trained teachers have developed their individual writing courses, and some new colleagues were engaged and instructed to teach writing at an academic level. In October 2012, a Workshop on Academic Writing was held at the English Department, Faculty of Philology, Sts Cyril and Methodius, R. Macedonia. It was organised in collaboration with the British Council, R. Macedonia. As Teresa 
O'Brien said at the opening of the 2012 workshop, "Much has happened in all our lives since November 2006, but our 2012 Workshop is testament to the consistency of purpose in the English Department here." The focus was put on assessment, teaching technical writing skills (graphs, reports) and argumentation. The team have undertaken to:

1. discuss further the potential of using writing portfolios and standardising the portfolio assessment criteria for each separate academic year;

2. reshuffle the genres and some of the units taught in different years;

3. teach analysis of argumentation and focus on strategies of avoiding fallacious arguments;

4. change topics for homework assignments since students found them unchallenging;

5. include teaching a BA proposal in year 4;

6. revise the materials on an annual basis.

The importance of this workshop was that a network of writing teachers from different universities in Macedonia was established. The team from Sts Cyril and Methodius has begun to network with teachers from five Macedonian Universities, which offer writing courses (SEEU, FON, University of Goce DelchevShtip, University American College, and State University of Tetovo). Workshops are eye-opening experiences since often it is hard to follow what other institutions do in a same country regarding certain curricula development.

\section{Theoretical foundations}

As a starting point in forming the theoretical foundations of a proposal for a writing curriculum, we can take Richards' statement that

in developing goals for educational programs, curriculum planners draw on their understanding both of the present and long-term needs of learners and society as well as the planners' beliefs and ideologies about schools, learners and teachers. (2001: 113)

Teaching is challenging, since it is never the same. It depends on factors such as interests, motivation and proficiency of students, and current globally acknowledged educational issues. Educators should not only be interested in what students learn, but also in what they want to learn. The teaching philosophy when proposing new writing curricula may be rooted in the concepts of educational accountability, in some aspects of the socio-constructivist theory, and in the context-based and research-based instruction.

From all the theories of teaching writing that appeared in the $80 \mathrm{~s}$ and $90 \mathrm{~s}$, a good writing curriculum synthesizes the focus-on-process, focus-on-purpose, focus-on-context and focus-on-research theories with the aim to ensure that students have a solid understanding of the processes of text creation, of the purposes 
of writing and ways of expressing these effectively through various rhetorical choices, and finally, of the contexts in which the texts are composed and read, so that both the writer and the reader are given the opportunity to negotiate meaning.

Important to be mentioned here is that if writing instructors decide to apply the focus-on-process approach, they should be aware that there is no single writing process, but there exist various individual processes. They should also be careful not to place too much emphasis on single process writing, because that could easily become a routine way of teaching (Graves 1994, Murray 1982).

In regard to theories of language and theories of learning, a successful writing curriculum should have two premises:

1. language is text- and discourse-based with focus of teaching how meaning and information are communicated and constructed via texts and discourse;

2. language is purposeful and students learn best when instruction addresses their needs (Richards \& Rodgers 2001: 207-210). In connection to how instruction addresses students' needs, what follows is a description of the concrete aims an educational institution or individual writing experts should have, along with the deeply rooted theoretical foundations when facing the challenge of establishing new writing curricula.

\section{Issues to be considered when designing L2 writing curricula}

Designing a good L2 writing curriculum at Foreign Language departments at any university, aiming at raising the profile of writing in a foreign language among students can be achieved through three specific aims:

Aim 1

Help students to learn how to read critically and write persuasively in various rhetorical contexts. To achieve this goal, the objectives will be for students to:

1. read and write in a variety of genres for distinct purposes and for a variety of audiences;

2. constantly practice the stages of the writing process: inventing, drafting, organizing, revising, and editing;

3. compose focused texts developed with details, examples, analogies, facts/ statistics, proper citations;

4. practice summarizing and paraphrasing material from existing texts;

5. master conventions of usage, spelling, punctuation, and sentence structure that affect clarity.

\section{Aim 2}

Train students to apply methods of finding and using appropriate information to various rhetorical contexts. To achieve this goal, the objectives for students will be to: 
1. brainstorm information;

2. use primary research methods such as observation and interviewing and incorporate the results into their texts, and use print and electronic sources to gather secondary information;

3. combine materials drawn from primary and secondary sources with their own ideas and experiences.

\section{Aim 3}

Help students to develop and demonstrate critical thinking abilities. To achieve this goal, the objectives for students will be to:

1. read closely, analyze, annotate, and evaluate a variety of texts (written both by peer-students and professionals);

2. analyze and discuss their own work through writing reflection papers;

3. analyze their peers' work through peer-editing;

4. design research questions, conduct primary and secondary research appropriate to answer the research questions and solve problems.

The expected outcomes of the proposed new curriculum are:

1. students will achieve better results in other courses that require good writing skills;

2. students will be able to write researched essays that are issue-oriented, focused, well-supported, appropriately organized, and properly documented;

3. students will feel comfortable with conventions of academic and professional discourses;

4. students will demonstrate an ability to assess the strengths and weaknesses of their own texts and their peers' texts which will help them prepare better for future language teachers, teachers of second language writing and translators or interpreters.

Another important issue to be taken in consideration when designing writing courses is that a high-quality writing course requires continuous evaluation and revision. Throughout the semester various types of evaluation should be carried out to assess the new curriculum design, the syllabus and the program content, as well as student and teacher progress. Student evaluation is usually based on their performance in class and the papers written. Self-assessment in a form of reflections can be combined with the other types of assessment. The formative evaluation is carried out by teachers who can monitor the course/curriculum as it develops and record what difficulties are encountered, as well as how efficient the materials are. As for the summative evaluation, students' views and results, the time spent on units, the homework load and grades determine the effectiveness of the curriculum.

Professional development of instructors who need training to teach writing is inevitable. Other teachers, except for writing instructors, can easily discover the power of writing and how it improves student learning and intellectual abilities (Nagin 2003). It is necessary that educational institutions in a country develop training sessions for teachers to improve the teaching of writing, both 
in L1 and L2. As research has pointed out, writing will not improve unless teachers are trained to teach it more efficiently. Training and development can be facilitated though engagement in international projects on improving literacy (e.g., Literacy Development in the Humanities). The LIDHUM project (2009-2012) is an institutional partnership project among Romania, Ukraine, Macedonia and Switzerland.

\section{Conclusion}

The purpose of this paper is to present the importance of initiatives for writing curricula design. By presenting an example of an initiative at a Macedonian university, I have offered suggestions what issues should be taken into consideration when proposing and designing new writing curricula. Experiences show that universities in the region (Balkan and South-East Europe) share some common features in regard to the writing programs and curricula. When teaching a foreign language at university to students who are majoring in that language, much more emphasis has been put on teaching vocabulary, grammar, and speaking, than on writing. Touching the theoretical foundations of teaching writing theories, I focused on the three major aims that should be followed when designing writing courses, and on the outcomes of existing writing curricula. I hope this paper will initiate research and a dialogue among writing instructors and educational institutions across the region in the areas of writing curriculum development and curriculum reform, effective research-based writing strategies, professional development of teachers to teach writing more productively. This is all with the aim to help students improve their writing skills in L1 and L2. This will make our students feel more confident and more compatible at foreign education institutions and the world job market.

\section{References}

Buzharovska, R. (personal communication, March 2009).

Georgievska, E., Kirkova-Naskova, A., \& Oncevska, E. 2007. Academic writing: from student learning to teacher learning. Godishen zbornik [Annual Collected Works at the Faculty of Philology], 31. Skopje: Filoloshki Fakultet.

Graves, D.H. 1994. A fresh look at writing. Portsmouth, NH: Heinemann.

Harrison, A.L. 2006. Teachers' perceptions of the development, enactment, and effectiveness of a new writing curriculum within the Elmore county public school district. (Unpublished doctoral dissertation). Auburn University, Auburn, Alabama.

Jordanovski, O. (personal communication, March 2009).

Murray, D.M. 1982. Learning by teaching. Portsmouth, NH: Boynton/Cook Publishers.

Nagin, C. 2003. Because writing matters: Improving student writing in our schools. San Francisco: Jossey-Bass. 
National Commission on Writing in America's Schools and Colleges 2003. The neglected " $R$ ": The need for a writing revolution. New York: College Board.

Reid, M., Bekar, M., \& Kirkova-Naskova, A. 2004-2005. Writing university project. Annual Collected Works at the Faculty of Philology, 30. Skopje: Filoloshki Fakultet, 233-235.

Richards, J.C. 2001. Curriculum development in language teaching. Cambridge: Cambridge University Press.

Richard, J.C., \& Rogers, T.S. 2001. Approaches and methods in language teaching (2 ${ }^{\text {nd }}$ ed.). Cambridge: Cambridge University Press. 